\title{
Sebastian Dec, Przemysław Frąckowiak, Michał Szykut (red.), „Wybrane zagadnienia profilaktyki, resocjalizacji i readaptacji społecznej w kontekście pedagogiki nadziei”, Próby i Szkice Humanistyczne, t. 7, Wyd. WWSSE, Środa Wielkopolska 2013
}

Recenzowana książka stanowi zbiorową publikację, której autorami są teoretycy i praktycy zajmujący się problematyką resocjalizacji. Odnaleźć tu można artykuły prawników, psychologów, pedagogów, pracowników naukowych z Polski i z zagranicy. Publikacja przedpremierę miała w Lęborku 05.07.2013 roku w czasie Międzynarodowej Konferencji: Profilaktyka, wsparcie i resocjalizacja, a środowisko lokalne. Perspektywy krytyczne. Inicjatorem tej publikacji jest Wielkopolskie Stowarzyszenie Kuratorów Sądowych oraz Pracownia Profilaktyki, Resocjalizacji i Readaptacji Społecznej. Redaktorami publikacji są: Sebastian Dec, Przemysław Frąckowiak oraz Michał Szykut. Pierwszy z nich pełni funkcję Dyrektora Zakładu Poprawczego w Poznaniu, kolejny jest Rektorem Wielkopolskiej Wyższej Szkoły Społeczno - Ekonomicznej w Środzie Wielkopolskiej, natomiast dr Michał Szykut jest kierownikiem Zespołu Kuratorskiej Służby Sądowej w Lęborku oraz pracownikiem dydaktycznym UMK w Toruniu.

Książka składa się z czterech części. Pierwsze dwie zawierają po osiem artykułów. Trzecia, której tytuł to Resocjalizacja w warunkach środowiska otwartego zawiera siedem tekstów. Natomiast ostatnia część - Resocjalizacja nieletnich $w$ warunkach izolacji społecznej, jest najmniejsza, gdyż składa się jedynie z czterech tekstów. Właściwe teksty poprzedza Nota metodologiczna. Próba nakreślenia mapy problemowej zagadnienia profilaktyki, resocjalizacji i readaptacji społecznej w kontekście, autorstwa Jolanty Spętanej, Anny Knocińskiej, Sebastiana Deca, Michała Szykuta oraz Przemysława Frąckowiaka, którzy są członkami Pracowni Profilaktyki, Resocjalizacji i Readaptacji Spo- 
łecznej. Autorzy zauważyli, że istnieje duża potrzeba poszukiwania rozwiązań z zakresu szeroko rozumianego ratownictwa społecznego, w które wpisuje się profilaktyka, resocjalizacja i readaptacja społeczna.

Warto zwrócić uwagę na fakt, że w części drugiej i trzeciej, oprócz tekstów w języku polskim, znajdują się również i te napisane w języku angielskim, autorstwa Marka D. Atkinsona oraz Roberta J. Cotterella. Mark D. Atkinson - sędzia z Austin (Teksas USA) - koncentruje swoje zainteresowania na przedstawieniu programu walki z przestępstwami popełnionymi przez osoby będące w stanie odurzenia alkoholowego, bądź narkotykowego. Robert J. Cotterell, dyrektor Okręgu Probacyjnego w Barnsley w Wielkiej Brytanii, jako doświadczony praktyk, dzieli się swoimi spostrzeżeniami dotyczącymi działań przeciwko przemocy w Wielkiej Brytanii na przykładzie programu IDAP - Integrated Domestic Abuse Programme. Roman Zielonka, pracownik socjalny na co dzień mieszkający i pracujący w Niemczech, podejmuje się opisu praktycznego wymiaru pomocy osobom trwale bezrobotnym w jego kraju. Autentyczność doświadczenia, praktyka, stanowi o sile tekstu. Powyższe wypowiedzi autorów sygnalizują międzynarodową aktualność publikacji.

Artykuł Tadeusza Frąckowiaka i Anny Kubiak pt. Aksjomat wsparcia społecznego rozwoju człowieka stanowi ważne wprowadzenie i podstawę teoretyczną dla kolejnych wypowiedzi. Autorzy zasadnie poruszyli kwestię utopii oraz mitu społecznego, gdyż jak sami zaznaczyli, „każde społeczeństwo jest powiązane systemem mitów, zespołem panujących form myślowych, które definiują i podtrzymują wszystkie jego czynności" (s. 22). Człowiek żyje w społeczeństwie, które na niego oddziałuje, w którym ma za zadanie pełnić określone role, którym nie zawsze jest w stanie podołać. Autorzy cytując J. S Colemana, R. D. Putnama, P. Bourdieu, A. Portesa, W. Woolcocka, nadali kierunek rozważaniom nad istotą kapitału społecznego w kontekście dobra. Na zakończenie pesymistycznie i niestety słusznie zauważyli, że współczesne społeczeństwo charakteryzuje raczej obcość międzyludzka niż wspólnota.

Autorką kolejnego artykułu znajdującego się w tej części jest Jolanta Spętana. W swej publikacji traktuje o granicznej sytuacji egzystencjalnej, którą trafnie zidentyfikował K. Jaspers. W interesujący sposób charakteryzuje trudności, które zestawia z nieodzownym ludzkim cierpieniem, problemem w dookreślaniu swojej tożsamości, na płaszczyźnie jednostkowej i społecznej.

Profilaktyka społeczna w kontekście wartości ewangelicznych to tytuł trzeciego artykułu w tym dziale. Anna Knocińska zauważyła, że profilak- 
tyka w swoich działaniach pomija bardzo ważne kwestie, na które składa się system wartości, poczucie sensu życia i istnienia. W dalszej części swego artykułu prezentuje rozumienie duchowości na przestrzeni wieków oraz wskazuje na możliwość uzyskania oczekiwanych efektów profilaktyki, pod warunkiem, że zwróci się uwagę na wartości ewangeliczne.

Wojciech J. Maliszewski skupił się nie na podopiecznych, lecz na osobach resocjalizujących. Podniósł kwestię ich przygotowania oraz kompetencji. Zaproponował metodę oddziaływania perswazyjnego, której cechy, strategie i warunki efektywności, wymienił na łamach recenzowanej książki. Wzbogacił tekst o autorskie wykresy oraz zamieścił szereg postulatów wskazujących na konieczność koncentracji na umiejętnościach interpersonalnych zarówno praktyków, jak i przyszłych resocjalizatorów.

Następne dwa rozdziały autorstwa Kazimierza Kotlarskiego oraz Elżbiety Stępy, stanowią bazę dla dalszych tekstów. Kotlarski wyjaśnia, że człowiek potrzebuje wsparcia na każdym etapie życia, którego nieodzownym elementem są zmiany. Natomiast Elżbieta Stępa przedstawiła trudności i zagrożenia czyhające na osoby w okresie dojrzewania. Dokonała krótkiego przeglądu koncepcji mających na celu zapobieganie nieprzystosowaniu społecznemu. Kolejny autor, mecenas Krzysztof Obolewski wskazuje problemy związane z przemocą $\mathrm{w}$ rodzinie $\mathrm{z}$ niekonwencjonalnego punktu widzenia, prawnika - wolontariusza $\mathrm{z}$ instytucji pomocy i wsparcia poszkodowanych. Autor łącząc doświadczenie adwokata i społecznika, stara się wskazać perspektywę koniecznych przekształceń rodzimego ustawodawstwa, związanego z sytuacją ofiar tego rodzaju przestępstw.

Pierwszą część zamykają refleksje z badań dotyczących integracji i tożsamości lokalnej mieszkańców Bornego Sulinowa, których autorem jest Andrzej Moniak.

Druga część pracy zatytułowana Wybrane zagadnienia profilaktyki społecznej oscyluje wokół rodziny, problemów związanych z przemocą, alkoholizmem, bezrobociem, a także samotnością.

Eugeniusz Kameduła oraz przedstawicielki Centrum Wsparcia dla Osób w Kryzysie w Lęborku Justyna Klinkosz-Pujsza i Joanna Weber, to autorzy dwóch tekstów dotyczących przemocy. E. Kameduła przedstawił trudności trapiące polskie szkoły oraz dokonał próby ustalenia przyczyn agresji i przemocy w tej instytucji. Dużym atutem artykułu jest poparcie opisu wynikami badań pilotażowych. Tekst przedstawicielek Centrum Wsparcia dla Osób w Kryzysie w Lęborku, to wartościowy informator statystyczny dotyczący przemocy w Polsce. Stanowi dobre źródło dla identyfikacji osób, które zgłaszają się do tego rodzaju instytucji pomocowych. 
W tematykę przemocy wpisuje się doskonale artykuł Krzysztofa Gieburowskiego i Hanny Gieburowskiej, którzy wskazali zasady działania zespołów interdyscyplinarnych na rzecz przeciwdziałania przemocy w rodzinie. Należy podkreślić, że tekst ten jest autorską analizą aktów prawnych, determinujących funkcjonowanie lokalnych zespołów interdyscyplinarnych.

Przyczynami przestępczości nieletnich zajęła się Renata Rasińska. Autorka upatruje ich w spożywaniu alkoholu i narkotyków, co udowadnia poprzez przedstawienie danych statystycznych. Alkoholizm i narkomania to temat tekstu dotyczącego funkcjonowania dorosłego rodzeństwa osób uzależnionych. Autorka akcentuje potrzebę dostrzegania rodzeństwa uzależnionych, jako jednej z grup wymagających pomocy i wsparcia. Artykuł oparty jest na wynikach badań własnych, zawiera dodatkowo transkrypcję rozmowy z osobą, której brat od wielu lat zmaga się z problemem alkoholowym.

$\mathrm{Na}$ trzecią część publikacji składają się teksty dotyczące resocjalizacji $\mathrm{w}$ środowisku otwartym. Jest to interesujący dział, gdyż wszystkie zamieszczone tu artykuły dotyczą funkcjonowania probacji w Polsce. Tomasz Siwiec, etyk, doktorant filozofii UMK w Toruniu, to autor pierwszego tekstu trzeciej części. Podjął się on trudnego zadania, jakim jest spojrzenie na etyczny wymiar pracy kuratora, poprzez krytyczną analizę Kodeksu Etyki Kuratora Sądowego. Autor wskazując na ważne uchybienia formalne i merytoryczne w kodeksie, zaproponował nowe obszary identyfikacji etyki kuratorskiej, łącząc je z pryncypiami życia społecznego. Jak sygnalizuje Autor, pozwoli to na skonkretyzowanie powinności moralnych kuratora oraz nakreślenie normatywnej przestrzeni jego działań.

Michał Szykut zwrócił uwagę na kwestię korzyści płynących ze współpracy kuratorów sądowych ze środowiskiem lokalnym. Postuluje poszukiwanie inspiracji dla tych działań i jednocześnie wskazuje, że jest to możliwe do zrealizowania. Potwierdza to przedstawiając aktywność kuratorów zawodowych, z Zespołu Kuratorskiej Służby Sądowej w Sądzie Rejonowym w Lęborku. Wielu informacji na temat, probacyjnego modelu kurateli sądowej w Polsce dostarcza także teoretyczny tekst Mariusza Kościelniaka.

Swoimi zagranicznymi doświadczeniami z wizyty studyjnej we Francji podzielił się Tomasz Dołotko, kurator specjalista w Sądzie Rejonowym w Lęborku, który w 2011 roku uczestniczył w zagranicznym stażu kuratorskim. System dozoru elektronicznego i opis funkcjonowania jego rodzimego wariantu, zarówno w teorii jak i praktyce, z uwzględnieniem wymiaru porównawczego, to tematyka tekstu Michała Miklińskiego. 
Analizowaną część dopełnia artykuł opisujący dobre praktyki związane $\mathrm{z}$ wykonywaniem kary ograniczenia wolności w postaci nieodpłatnej kontrolowanej pracy na cele społeczne, na terenie gminy Września.

Ostatnia część publikacji nosi tytuł: Resocjalizacja nieletnich $w$ warunkach izolacji społecznej. Trzy z czterech referatów, dotyczą środowiska zakładów poprawczych. Przemysław Frąckowiak oraz Sebastian Dec za pomocą wielu schematów zapoznają czytelnika z mikrosystemem resocjalizacji, sytuując go w konkretnej placówce wychowawczo-resocjalizacyjnej.

Ciekawy wątek poruszyła również Małgorzata Paczyńska-Jędrycka. Autorka doceniła rolę wychowania fizycznego, które pozytywnie wpływa na fizyczność i zdrowie człowieka w każdym wieku. Przedstawiła badania przeprowadzone w 2011 roku, w zakładach poprawczych, dotyczące aktywności fizycznej, jako koniecznego elementu procesu resocjalizacji.

Równie ciekawy temat, ukazujący podopiecznych zakładów karnych, zainicjowała Anna Kruszyk-Pytlik, której tekst dotyczy dzieciństwa, widzianego oczami młodych ludzi przebywających w zakładzie poprawczym.

Część czwartą i jednocześnie całą recenzowaną książkę, kończy artykuł stricte związany z pedagogiką: Modelowanie jako warunek skuteczności wychowania resocjalizującego. Jest to trafny wybór wiążący całość książki, który przypomina o kształtowaniu relacji międzyludzkich, o inspirujących kontaktach wychowawcy i wychowanka.

Resocjalizacja wciąż boryka się z negatywnymi opiniami. Można zadawać pytania, czy jest ona skuteczna? Kiedy widać jej efekty? Może nie jest skuteczna, bo jest źle realizowana? Może jakiś element został w tworzonych projektach przeoczony? Jak organizować wsparcie dla działań resocjalizacyjnych? Czy środowiska lokalne są gotowe afirmować i wspierać pracę ratowników społecznych? Autorzy tekstów recenzowanej publikacji starają się wskazywać kierunki dla dobrych rozwiązań i wykorzystywania skutecznych praktyk.

Zaakcentowany w tytule przez redaktorów publikacji termin pedagogika nadziei, to trafny kierunek dla refleksji na kluczowe dla książki tematy. Przecież tak bardzo w pracy ratowników społecznych potrzebna jest akceptacja i wsparcie. Znaczenie nadziei podkreślił również Stanisław Chrobak twierdząc, że „życie według nadziei i działanie z nadzieja stanowi fundament egzystencji jednostki oraz społeczeństwa. Nadzieja, motywując i dynamizując podejmowane przez człowieka działania, przyczynia się do jego wszechstronnego i petnego rozwoju ${ }^{1}$.

1 S. Chrobak: Pedagogika nadziei. Współczesne konteksty w inspiracji personalistyczno - chrześcijańskiej, Wyd. Uniwersytetu Kardynała Stefana Wyszyńskiego, Warszawa 2009, s. 13. 


\section{8 | Wybrane zagadnienia profilaktyki, resocjalizacji i readaptacji społecznej}

Zachęcam do lektury recenzowanej książki ze względu na bogactwo tematyki, sposobu ich przedstawienia oraz interdyscyplinarnego, pedagogiczno- prawniczego i filozoficznego podejścia do resocjalizacji i readaptacji społecznej. Aktualność wielu wypowiedzi autorów czynią publikację atrakcyjną, zarówno dla teoretyków i praktyków resocjalizacji, ale także co szczególnie ważne, dla przedstawicieli środowisk lokalnych oraz studentów.

Joanna Kamińska 